\title{
Langvinnir lífsstílssjúkdómar - mesta ógn nútímans við heilbrigði
}

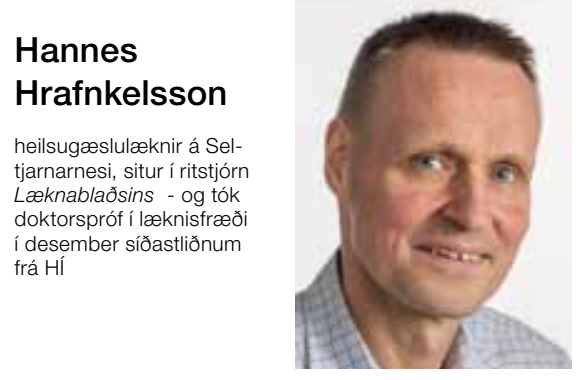

Hannes.Hrafnkelsson@heilsugaeslan.is

Langvinnir lífsstílssjúkdómar valda nú pegar 86\% af öllum dauðsföllum í Evrópu, eins og fram kemur í ágætum yfirlitsgreinum í nóvemberblaði og í pessu blaði. Beinpynning er pó ekki talin meðal pessara langvinnu lífsstílssjúkdóma en $40 \%$ einstaklinga geta búist við að beinbrotna vegna beinpynningar á lífsleiðinni og veruleg áhrif má hafa á sjúkdóminn með lífsstíl. Pessir sjúkdómar valda pví að stór hluti lífeyrispega mun ekki lifa við heilbrigði síðustu áratugi lífsins, heldur lifa með einum eða fleiri langvinnum sjúkdómi. Petta veldur gífurlegri skerðingu á lífsgæðum ásamt miklum kostnaði, bæði fyrir einstaklingana og samfélagið. En einnig kemur fram að pessari próun má snúa við og að 80\% lækkun á dánartíðni hjartasjúkdóma á síðustu 25 árum hjá körlum og konum yngri en 75 ára má að langmestu leyti rekja til breytinga á lífsstíl, par sem minnkandi reykingar og breytt mataræði vega mest en lyfjameðferð og tækniframfarir útskýra einungis lítinn hluta. Рað er pví ljóst að pótt við fáum nýjan spítala, betri greiningartæki og lyf sem virka betur og hafa færri aukaverkanir, mun pað hafa lítil áhrif á tíðni og nýgengi langvinnra sjúkdóma. Ef fækka á langvinnum sjúkdómum og bæta lífsgæði verður að ráðast að orsökunum. Pannig er hægt að vinna stóru sigrana. Nú pegar hefur mikill árangur náðst á vissum sviðum og má par nefna að stöðugt færri reykja og 1 dag sjáum við jafnvel fram á að Ísland verði reyklaust innan 20 ára. Einnig hefur matarog nestismenning í grunnskólum batnað. Раð er engin önnur leið til að verjast langvinnum sjúkdómum en að breyta um lífsstíl par sem reykleysi, bætt mataræði, hæfileg hreyfing og aukið pol skipta mestu máli. Enginn skyldi treysta á að lyf og tækni geti komið í stað hollra lífshátta.

Langvinnir lífsstílssjúkdómar eiga pað sameiginlegt að peir eru oft áratugi að próast. Rannsóknir sýna að börn og ungt fólk er oft á tíðum komið með breytingar á kransæðum og að líkurnar á breytingum aukast eftir pví sem áhættupáttum fjölgar. ${ }^{1}$ Rannsóknir á íslenskum 9 ára börnum sýna að pau sem hafa betra pol hafa að meðaltali marktækt hærra HDL, lægri príglýseríða og lægra fastandi insúlín - allt petta getur mögulega dregið úr áhættu á langvinnum sjúkdómum í framtíðinni. Auk pess hafa pau börn sem hafa betra pol marktækt hærri beinpéttni. ${ }^{2}$

Á heimasíðu Embættis landlæknis koma fram ráðleggingar um heilsu og líðan allt frá meðgöngu til elli. Par koma meðal annars fram bestu ráðleggingar byggðar á vitneskju nútímans um hreyfingu og fæðu barna. Meginráđleggingin er að börn hreyfi sig rösklega í minnst 60 mínútur daglega. Enn er langt í land að meirihluti 9 ára barna nái peirri ráđleggingu samkvæmt íslenskri rannsókn. ${ }^{3}$ Einnig tekur lítill hluti 9 ára barna lýsi og D-vítamínskortur er algengur meðal íslenskra barna svo eitthvað sé nefnt. Í raun er undarlegt að foreldrar og yfirvöld leggi ekki meiri áherslu á að leiðbeiningum frá Embætti landlæknis sé fylgt. Allt bendir til að ef pað væri gert, bætti pað líðan og minnkaði verulega líkur á sjúkdómum, bæði til skemmri og lengri tíma. Pví miður kemur pað hins vegar ekki á óvart að á meðan 800 milljónir eru lagðar í að skipta út úreltum tækjum á Landspítalanum, minnist enginn á að pað purfi meira fjármagn til að bæta lífsstíl barna. Мeð sömu upphæð mætti sennilega bæta líðan og minnka líkur á langvinnum sjúkdómum hjá mun fleirum en ný tæki geta gert.
Eins og fram kemur í greininni um langvinna lífsstílssjúkdóma hefur European Chronic Diease Alliance sett sér mælanleg markmið um fækkun langvinnra sjúkdóma. Íslendingar ættu að eiga auðvelt með að ná öllum peim markmiðum sem nefnd eru, sé rétt á málum haldið. Einnig ætti að stefna að fleiri markmiðum sem auðvelt væri að ná, svo sem að fækka í peim hópi sem hreyfir sig minnst og er með lélegast pol og bæta D-vítamíninntöku hjá peim mikla fjölda sem fær minna en ráðlagðan skammt af D-vítamíni, svo eitthvað sé nefnt.

Öll viljum við eiga gott sjúkrahús með góðum tækjabúnaði og miklum mannauði. раð má hins vegar ekki gleymast að ekki er síður mikilvægt að fjárfesta í hollu líferni peirra sem nú vaxa úr grasi, með áherslu á reykleysi, ráðlagða hreyfingu, hollan mat, umhyggju og samveru. Takist okkur vel á peirri leið minnkum við líkurnar á að sú kynslóð purfi að pjást af langvinnum sjúkdómum og aukum líkur á að hún lifi heilbrigð fram eftir aldri. Er hægt að hugsa sér betri gjöf fyrir börnin okkar?

\section{Heimildir}

1. Berenson GS, Srinivasan SR, Bao W, Newman WP 3rd, Tracy RE, Wattigney WA. Association between multiple cardiovascular risk factors and atherosclerosis in children and young adults. The Bogalusa Heart Study. N Engl J Med 1998; 338: 1650-6.

2. Hrafnkelsson H, Sigurdsson G, Magnusson KT, Sigurdsson EL, Johannsson E. Fat mass increase in 7-year-old children: More Bone Area but lower Bone Mineral Density. J Bone Miner Metab 2013. [Epub ahead of print]

3. Magnusson KTh, Arngrimsson SA, Sveinsson Th, Johannsson E. Líkamshreyfing 9 og 15 ára íslenskra barna í ljósi lýðheilsumarkmiða. Læknablaðið 2011; 97: 75-81.

Chronic non-communicable diseases: - The greatest threat to modern health

Hannes Hrafnkelsson MD, PhD General Practitioner

Seltjarnarnes Health Care Center, Seltjarnarnes, Iceland 